\title{
Reflection of Leadership Learning in Classic Stories as the Innovation of Literary Education
}

\author{
Abdurahman \\ Indonesian Language and Literature Education Program \\ Faculty of Languages and Arts, Universitas Negeri Padang \\ Padang City, Indonesia \\ abdurahman.padang@gmail.com
}

\begin{abstract}
This paper aims to explain the reflection of leadership learning in the Minangkabau (Indonesia) classic story in which leadership learning is described as having made a good leader called "penghulu". The phenomenon of leadership learning in classical stories is an interesting phenomenon to discuss because the topic of leadership is still actual until today. In my research in 2013 about the cultural wisdom in the Minangkabau classic, with qualitative methods, and data derived from the text of the story, I have found several stories that talk about leadership learning. Among the classic story titles are the stories "Kaba Rancak Dilabuah", "Kaba Sutan Lanjungan", "Kaba Cindua Mato", "Kaba Magek Manandin" and "Kaba Sabai nan Aluih". Reflections on leadership learning are described in the form of descriptions and dialogue between children and parents, and about how a leader behaves in his community. In addition, they also describe the kind of good leader and evil leader. Based on the research findings, this paper will discuss the theoretical concept of leadership which is then associated with the implementation of leadership learning in classical stories, leadership learning materials, and the types of leaders that are reflected in the story. This paper also aims to explain the importance of the message of leadership in the classic story as an innovation of language and literary education so that literary education can be used as an education based on cultural values of the nation.
\end{abstract}

Keywords---leadership learning, classic story, educational literary

\section{INTRODUCTION}

Folklore as part of the results of cultural activities in the past, has a link with the learning activities of community life, both the community who gave birth to it and the people who read it until now. In connection with that, Ratna states that the society associated with a literary work is a society of creators of literary works, the community contained in literary works, and the public readers of literary works (Ratna, 2007). The three types of society, whether in the old literature or in modern literature, the community certainly have certain characteristics. In folklore, the old society has made it happen and its contents are the problems of the old people's life as well, that is about the problems of people's lives in the past. Furthermore, the people who read the folklore are the old society and the present society. That is, the reader community is a society that interacts with literary works and messages reflected from the cultural life of the old society that exist in folklore has been a learning for them. Accordingly, the title of this paper begins with the word 'reflection' because this paper is attempted to discuss the reflection of past societies about the leadership learning that is in it.

Folklore as an old cultural reflection contained various aspects of cultural learning (Abdurrahman, 2011). One of the many aspects of cultural learning reflected in old literature is learning about leadership that is told through storytellers. The concept of learning and the linkage with the old culture can be seen as a process that occurs among storytellers who indicate the existence of cultural inheritance by learning. Budianto states that a meaningful life does not just come but through a process and a learning effort. Self learning begins when the human being realizes and seeks to mean that he has an integrated body and spiritual elements with various aspects and functions that interwoven in such a way as a unity that has a purpose in life (Budianto, 2004). Learning occurs when people realize and think that besides themselves there are others who are equal to him, who are both need each other and need among them. In addition, learning occurs because people realize that it is placed on earth that must be processed and looked for solutions to the challenges it raises

The spreading of life has resulted in cultural behavior related to various activities of his life. Behavior resulting from learning that there is a meaningful and useful for life and does not harm others. There is a meaningless behavior that in its application tends to harm others. One of the many good behaviors learned in life depicted in folklore is a matter of leadership. Northouse states that leadership is a high-commodity topic because people keep questioning themselves and others, about what can make a person a good leader who can improve their personal, social, and professional lives (Northouse, 2013). That is, the problem of leadership and learning is a theme that is always a human attention to realize a better life culture.

At the present time, it is not surprising that leadership topics have been discussed by researchers in various fields including in the field of humanities. According to Northouse there are many experts who have discussed about the leadership process such as Gardner, 2009; Mumford, 2006: Jackson \& Uhl-Bien, 2011; Day \& Antonakis, 2012. They have studied leadership qualitatively and quantitatively (Northouse, 2013). Furthermore, Northouse defines leadership as a process whereby individuals influence groups of individuals to achieve common goals. An important description of leadership is leadership style, which is trait 
leadership, skill leadership, leadership style, situation leadership, transformation leadership, leadership serving, leadership, and authentic leadership. Kartono states that the leader is someone who has the skills and advantages in one area so that he is able to influence others to jointly perform certain activities, for the achievement of one or some particular purpose (Kartono, 1998). Generally the leadership study is a broad and need to be limited for the purposes of this paper.

Related to that, in this paper discussed the aspects of leadership in folklore in terms of leadership learning related to action figures that have shown the existence of learning activities about leadership. Specifically in this description will be observed the behavior of teaching and learning among story characters about leadership as well as learning strategies and leadership learning materials discussed in the folklore.

In a study I conducted in 2013 on cultural wisdom with the objects of the ten Minangkabau folklore, I have found several folklores discussing leadership and leadership practices. Among the prominent Minangkabau folklore of the story are Kaba Cindua Mato (2008), Kaba Sabai nan Aluih (2004), Kaba Tapian Larangan (1982), Kaba Sutan Lanjungan (1982). In general, the folktale recounts or reflects the importance of leadership in life.

In this paper, the discussion focuses on leadership learning that is in Kaba Rancak Dilabuah (KRD) (2008) because this story is more specifically reflects on leadership learning. The description of leadership can be observed on the character Siti Jauhari with two children, namely Rancak Dilabuah and Siti Budiman, who has been carrying out leadership learning in the household. In addition, one part of the KRD story contains the title of being a leader (penghulu). Amir (2009: 97) states that KRD is a story containing teachings about the leader (penghulu) delivered with people's expression.

In connection with the focus of the above discussion then the question that needs to be answered in this paper is who the perpetrators and how the leadership in learning activities in folklore? What is the leadership strategy in folklore, and what leadership materials are taught in folklore? Furthermore, the answers and discussion of these questions will be tied to innovations in literary learning in schools.

Furthermore, innovation in the literary learning in schools is associated with leadership learning materials, is a discussion of the need for literary learning is emphasized on aspects of life that are needed by students in their life. Such learning can be sourced from literary works such as folklore. Such a thing, is a learning based on global culture and local culture. The meaning of literary learning has a plural contribution that allows the side gets various kinds of intelligence in addition to intellectual intelligence. Emzir and Rohman (2015: 232) argue that cultural-based learning is a growing learning in various countries aimed at the preservation of local culture. This discussion can contribute to the renewal of literary learning in schools where our students are expected after learning grows smarter in addressing the old culture and widening their insights about traditional leadership themes.

\section{METHOD}

Research method used is descriptive method that describes the behavior of the perpetrators of the story in leadership learning that existed in folklore. Formal data is part of the story taken from the text of the story script that shows leadership learning. Furthermore content analysis techniques are required to express symbolic meanings disguised in folklore texts (Endoswara, 2008)[9]. In addition, the analysis techniques proposed by Mayring (2000) is to determine the object of research, analyze the context of the story, determine the characteristics of the story, determine the technique of analysis and interpret data [10].

In the study of the disclosure of leadership learning in folklore, the object under study is the folktale with the title Kaba Rancak Dilabuah (KRD) published in 2008 by Datuk Panduko Alam, published by the publisher of Crystal Multimedia. In this discussion the symbolic message is the leadership learning in KRD while the cultural context is Minangkabau culture. Besides, the opinion of Moleong (1990) which states the process of data collection, analysis, and interpretation of data can be implemented simultaneously and integrated.

\section{FINDING AND DISCUSSION}

\section{A. Reflection of Leadership Learning in KRD Stories}

In this section we describe the findings of reflection on leadership learning in KRD stories based on the data and their relation to the cultural context that supports them, namely the Minangkabau ethnic group culture. Talks about the reflection of leadership learning in KRD are outlined in accordance with the formulation of the problems mentioned in the previous section. The discussion is followed by a discussion related to the findings with thoughts about the innovation of literary learning in schools.

1. Doers and Forms of Leadership Learning in KRD Stories

The first question to be answered is who is the actor and what is the form of leadership in learning in KRD folklore? In KRD the participants of learning about leadership are story characters, namely Siti Jauhari with two children, namely Rancak Dilabuah and Siti Budiman. Learning takes place in some form of informal activity, and learning activities take place inside their home. Siti Jauhari is a teacher and her two children are her students. 
Siti Jauhari is the mother who became single parent because it is not married and in educating his son he is alone. He has two children and his two children get education from him. He is told as a woman who once studied to his father Tuanku Rajo Bana. Therefore in everyday life he is a diligent and educated woman so that he knows which culture is good and true and he knows also the wrong culture and should be avoided in life. He is a wise and clever woman who determines where the noble character and where temperamental nature (KRD, p 5).

In relation to the reflection data of leadership learning in KRD story, after the researcher identified from eleven parts of the story, it turns out that each part of the story contains learning activities between the storyteller, Siti Jauhari with his son. The first part of the story with the subtitle "Mampaturuikan Hati Gadang", there is learning about the need for children to change their life orientation from a life that is only based on passion to be a child who understands the purpose of life based on customs and religion.

The author's message in the first part of the story is that children do not live a worldly life and children do not pretend that such a life is just like a mirage. On the one hand, the performance of the child is seen by others as rich and honorable, whereas in fact he is just a poor, uneducated, and misbehaving person who is unfavorable to the family. Such a life style is more harmful to the child and the family, and his behavior can not be an example in his society. Such a reality in the KRD is called the phrase, "rancak di labuah" or "dashing in the streets".

On page 1-19, told the lifestyle of the figure Rancak Dilabuah, he is a person who likes to live fun, likes to owe and like to mortgage rice fields or family fields. When the money comes to an end, he loses his way of paying the debt, and he feels the life is narrow and he is treated badly by the loan shark if he does not pay his debt. In that panic, he complained to his mother and his mother scolded him with figurative words. Prior to that incident, his mother had also given advice and restrictions so that he did not behave badly and follow the passions. Rancak Dilabuah has endured the pain because of his temperament he finally obeys his mother's advice and wants to learn about the culture of life and how to live life with his mother. After that, her mother wisely taught her with basic ethics about life, such as how to control yourself, how to eat, and how to speak. With the learning of his mother, he became a good and obedient child to his mother.

Leadership learning reflected in the first KRD is a child is a potential leader, therefore the child should be educated and taught in his or her household neighboring true life orientation, life goals, attitude and good life, good behavior, ethics in family life and community. The reflection of leadership learning in this section is related to the ability of parents to prepare themselves for individual children for a strong and good personality and can control themselves in life.

In the second part of the KRD story entitled "Maaliah Gala" (p, 20). In it is told story character Siti Jauhari successfully educate Rabak Dilabuah become a child who wants to work and try to cultivate his fields. Rancak Dilabuah clever trade and in various fields of business that he had also studied diligently to his mother. In addition, Siti Jauhari has taught her child the ways and ethics of socializing (, $22-26)$, that is how to connect with the elderly, connect with peers / aged, and connect with younger people. In addition, Rancak Dilabuah is taught how to treat a person in everyday culture and associate with people in traditional parties.

Leadership learning reflected in the second KRD is a child who will be a candidate for leader, must have been educated and taught in his or her household life skills to work in order to earn a steady income for living expenses. In addition, children are taught about the right social life, and various ethics of socializing in the activities of community life. The reflection on leadership learning in this section is related to the ability of parents to prepare themselves as individuals who are able to socialize to be accepted in community life and directed strongly and well in order to control other people and society in life.

In the third part of KRD's story "Urang Sumando" (p, 28-33). In it is told the perpetrators of the story Siti Jauhari test Rancak Dilabuah find someone who behaves well to be her sister's husband. In the process and the search effort, he had put several names to his mother by mentioning the person's traits. However, his efforts were not successful because his mother rejected his choice. According to his mother, the person he chose had a disgraceful nature. Rancak in Labuah handed the matter over to his mother, and afterwards, his mother showed him his favorite name and mentioned the good qualities of the child that he wanted and the nature of their customs and ethics.

Leadership learning reflected in the third KRD is a child who is a potential leader, must have been educated and taught the ability to distinguish the characteristics of good people and people who are not good. Moreover the person will be a family member to become the husband of beloved sister or son-in-law. If someone is choosing will certainly make the family becomes not harmonious or there will be chaos in the family. Conversely, if a good person is elected then family circumstances and kinship relations will go well and family members will be at peace. In addition, children are taught about the right social life, and the results of socializing in community life activities will increase the progress of family quality. Reflection on leadership learning in this section is related to the ability of parents to prepare themselves as individuals who are able to put individuals into acceptance in family life and in the community.

In the fourth part of KRD story "Urang Sumando" (p, 35-41). In it is told the perpetrators of the story Siti Jauhari teach his daughter, Siti Budiman, about the responsibility of being a wife. Siti Jauhari teaches how to be a good wife, how to communicate with husband, the need for character as a wife when dealing with other people, and the types of women and the nature that is not good as a wife. In addition, Siti Budiman taught his mother how to care for and educate children in the family. The fourth part of the KRD story focuses more on education on the responsibilities of women in the household. 
Leadership learning reflected in the fourth KRD, a child who will be a potential leader must be accompanied by a good woman as a friend of his life. Therefore, in KRD learning about how a woman's responsibility in her home is closely related to the success of a leader. If the wife of a leader is a woman of good and virtuous character of course she will contribute greatly to the success of her husband in the lead. A good woman will give her husband good input and the bad woman will give irrelevant consideration to her husband's leadership. The existence of a woman determines the success of her husband in the family and society.

For the fifth part to the eleventh part of the KRD story, this author will briefly discuss so that the writing page is not too much. In the fifth part, the figure Rancak Dilabuah asked people to be the husband of his son named Puti Cito Dunia. She is a good and good woman. The learning of leadership that is reflected in this section is that a leader must have a wife who can take care of his own family. Culturally in Minangkabau culture a boy can not be called as an intact individual if not married. Therefore, fostering a household for a leader is a unity of responsibility as a man.

In the sixth part, Siti Jauhari taught Rancak Dilabuah how someone in negotiating and agreement between them. They make arrangements to be fulfilled by providing an ornament as a sign of agreement. In this section the story of KRD is more to teach the reader how to respond and keep the promise as an obligation. A leader must surely keep his promise as an obligation.

In the seventh section ( $\mathrm{p}, 52-56)$, the KRD story contains learning of how a husband's responsibilities in the household. In it also mentioned six types of husbands with their respective traits. Of the six types, five types of husbands are not good and one kind of good husband. A good husband is a husband who can add goodness to family and wife in various aspects of life. Leadership learning reflected in the sixth KRD is a child who is a potential leader, should be taught the ability to manage household well. This means that before he gets mandate as a higher leader, he should be able to lead the family well.

In the eighth to the tenth part, the KRD story contains the lead strategy, the knowledge of the leader, the type of leader, and the procession of custom leaders' appointment. Among the content of the leader is a leader must know the laws and proficient in practicing it to realize justice in leadership. Leadership learning reflected in the KRD is a child who is a potential leader, must have been educated and taught leadership skills formally and knowledgeable about the laws and strategies to serve the people he leads. In general it can be said that to successfully lead a society, one must have leadership science. KRD story tells a lot about leadership in Minangkabau culture. A highly emphasized leadership aspect is that a leader must understand and understand how to lead Minangkabau and the Islamic religion. In addition, a person who is a leader must have intellectual intelligence and emotional intelligence. A good leader based on custom and religion is a people's dream.

The last part of KRD, the eleventh section tells about the attitude and nature of being young and the nature of life after old age. The story of KRD formulates that trait with the topic of the story, unfortunate when young and unfortunate when old age. Both are attitudes and traits that are not good used by young people and parents. In addition, there are ten properties of hatred and ten also the favorite properties that need to be considered in life. Leadership learning reflected in this section of KRD is a leader, from a young to an old age, should be consistent with the nature of the mind and can avoid the nature of hatred.

Leadership learning reflected in KRD is a whole and real leadership learning in life. What is meant by intact learning is the leadership taught by KRD story in terms of self-leadership, family leadership, kinship leadership, community leadership, and the leadership of the country. Based on the discussion, it can be concluded that KRD story contains leadership learning which is reflected in KRD story through storyteller Siti Jauhari and his two children.

\section{Strategy and Leadership Learning Material in KRD Stories}

After the KRD story was analyzed found several learning strategies used in leadership learning activities. The lesson strategy meant here is the way in which the educator engages in learning and facilitates the student to learn. Here are some prominent strategies or lessons learned in the KRD story. First, the character Siti Jauhari directly gave advice to Rancak Dilabuah by giving understanding about the error of his son in behaving. The way it gets the answer from the child and they engage in dialogue with different opinions. Nevertheless, Siti Jauhari still appreciate his son's opinion even though his son's opinion is different from his advice. Such a picture is found in the first part of the KRD story.

The second strategy is Siti Jauhari scolding the child with the word figuratively and persuading the child to return to the truth. The strategy is able to awaken the child so that his son would follow his advice to turn into a good child. After becoming a good child learning is delivered in several ways among them by offering an opinion for consideration (p 22). In addition, Siti Jauhari also uses a way of questioning, discussion, and testing. In the material part of leadership (p, 74) Siti Jauhari gave the subjects teaching material then he told his son to explain about what the purpose and explanation of the material.

In learning among characters KRD story, the way is also taken is to provide teaching materials by way of mentioning the number and nature of the learned. For example, there are six kinds of sons-in-law, and afterwards the teacher discusses one by one of those types by giving descriptions and examples. An interesting way is also the name of the learned traits taken from the names of animals and plants that exist in their natural surroundings. For example, bad son-in-law type, "green fly"-in-law, "kitchen-cat"in-law and others.

From data on learning strategies and their relation to leadership teaching materials, it can be concluded that leadership leadership strategies used in KRD stories varies. Siti Jauhari provides learning in different ways to give different learning materials. A prominent learning strategy is by direct method, discussion, giving examples, question and answer, and teacher 
asking for explanation. Learning is enthusiastically portrayed where teachers love to teach and students are eager to learn. An interesting way in KRD story is that students are taught by hands-on practice to gain experience. This method of course reminds us of how to learn through direct experience and practice.

\section{B. Discussion}

After the KRD story has been discussed, it has been found that leadership learning is in the KRD story, which is learning activity between Siti Jauhari and his child with leadership material for self, family, and society. The taught leadership material comes from Minangkabau wisdom teachings. This is known after KRD story of leadership is seen in some Minangkabau custom reference books. In between, the book that fits the KRD story is the Minangkabau Tambo (Ibrahim, 2009). Minangkabau custom book by Amir (2007), Ilyas (2010), Julius (2007), Latief (2002), Navis (1995).

Reflections on leadership learning in KRD can be expressed as direct and indirect reflections. Reflection of learning that is directly characterized by speech leaders of leadership by calling directly the words of leadership in learning. In this case, the storytellers teach leadership in order to achieve leadership coexistence on the students. In contrast, the reflection of incomplete leadership learning is a leadership lesson that does not directly address the aspects of leadership but the expected attitudes and behaviors of learning become the supporting aspects for the formation of leadership traits. With such learning reflection indications, the KRD story is a reflection of leadership in the form of direct and indirect learning from the Minangkabau leadership style. Emzir (2015) states that literary work is a social document that records societal societal culture when the work was created.

The leadership reflection discussed in the KRD story is interesting when associated with school literary learning. First, the child has his own power to seek, try, find and develop himself. Thus, all that knowledge must be obtained by observation, experience, inquiry, and learning will be meaningful if the student "has experienced what he or she has learned". What KRD's story reflects on that thought.

Second, many educational experts hold that the importance of direct involvement of students in the learning process. John Dewey with his "learning by doing" enables the learning to be experienced through direct deeds and must be done by the students actively. In the KRD story it has been reflected that Rancak Dilabuah is directly involved with leadership learning. and more interestingly. Edgar Dale in the classification of learning experiences suggests that the best learning is learning through direct experience.

Furthermore, to innovate the learning of literature in schools we should include the old literary materials, especially those charged with local culture such as leadership culture. If this can be expected, the result can be a contribution to the students in the development of insights in the field of local culture, especially in terms of leadership. It certainly can be a catalyst that gives a sign in addressing the global cultural rush that is not necessarily in accordance with our nation's culture.

\section{CONCLUSION AND RECOMMENDATION}

Folklore as a cultural activist of the past has become a cultural document that contains a picture of society when the work was created. One of the many cultures described is the reflection of leadership learning. In the reflection of learning we can understand how leadership competencies are cultivated in a learning that takes place in families with varying strategies. Leadership in the life of the community told by the author of the story is a cultivated by learning. As a society that continues the good culture in life, students need to learn the culture presented in the literary work so that they do not lose the wisdom of words and culture. In the KRD story culture that is told especially the culture of leadership is a good and universal teaching. The message of leadership that is in it is no less good with the teachings of today's leadership.

In connection with that, it needs to be realized literature-based learning of local culture with local literature as a source of learning. Folklore is one of the most important sources for it. Because folklore is necessary, there must be an act of providing literature in a modern way to be easily accessible to students. The author suggests that information technology be used to facilitate the learning of literature based on local culture with varied learning approaches.

\section{References}

Abdurahman, A. (2011). Nilai-nilai Budaya dalam Kaba Minagkabau, Suatu Interpretasi Semiotik. Padang: UNP Press. Abdurahman, A. (2013). Pesan Kearifan Budaya dalam Kaba Minagkabau. Padang: Universitas Negeri Padang.

Alam, Dt. P. (2008). Kaba Rancak Dilabuah. Bukittinggi: Kristal Multimedia.

Amir, M. S. (2007). Adat Minangkabau, Pola dan Tujuan Hidup Orang Minang. Jakarta: PT Mutiara Sumber Widya.

Amir, A. (2009). Kapita Selekta Sastra Minangkabau. Padang: Minangkabau.

Budianto, I. M. (2004). Ideologi Budaya. Jakarta: Yayasan Kota Kita.

Emzir. \& Rohman, Saifur. (2015). Teori dan Pengajaran Sastra. Jakarta: PT Raja Grafindo Persada .

Endoswara, S. (2008). Metode Penelitian Sastra. Yogyakarta : Medpress.

Ibrahim, Dt. S.D. (2015). Tambo Alam Minangkabau. Bukitinggi: Kristal Multi Media.

Julius, H. (2007). Mambangkik Batang Tarandam dalam Upaya Mewariskan dan Melestarikan Adat Minangkabau Menghadapi Modernisasi Kehidupan Bangsa. Jakarta: CV Arena Seni. 
Latief, H.Ch. N. (2002). Etnis dan Adat Minangkabau Permasalahan dan Masa Depannya. Bandung: Penerbit Angkasa. Kartono, K. Pemimpin dan Kepemimpinan. Jakarta: Raja Grafindo. 1998

Mayring, P. Quantitative Content Analysis. http://www qualitative resarch net/htm. 2000 